DOI: $10.4274 /$ tpa. 46.50

\title{
Ergenlik çağında bağ dokusu hastalıkları
}

Connective tissue diseases in adolescence

\author{
Özgür Kasapçopur, Nil Arısoy \\ istanbul Üniversitesi Cerrahpaşa Tıp Fakültesi, Çocuk Sağı̆̆ı ve Hastalıkları Anabilim Dalı Çocuk Romatoloji Bilim Dall, İstanbul, Türkiye
}

\section{Özet}

Ergenlik çağında görülen bağ dokusu hastalıklarının klinik gidişi ve bulguları diğer çocukluk çağlarından oldukça farklıdır. Hem hastalıklar hem de klinik gidiş bu dönemde belirgin değişkenlikler gösterir. Bu derlemede ergenlik çağında görülebilen bağ dokusu hastalıklarının gözden geçirilmesi amaçlanmıştır. (Türk Ped Arş 2011; 46 Özel Sayı: 118-27)

Anahtar sözcükler: Ergenlik çağı, bağ dokusu hastalıkları

\section{Summary}

The clinical course and symptoms of connective tissue diseases in adolescence is different from the other childhood periods. Both diseases and clinical courses of diseases show significant variations in this period. In this article, it is intended to review connective tissue diseases that can be seen in the adolescence. (Turk Arch Ped 2011; 46 Suppl: 118-27)

Key words: Adolescence, connective tissue diseases

\section{Giriş}

Ergenlik dönemi çocukluktan erişkinliğe geçiş dönemini içerir. Oldukça uzun ve sıkıntılı olan bu süreçteki çocuklarda görülen hastalıklar genel çocuk hekimliğinde görülenlerden farklı klinik bulgular ile ortaya çıkar. Ergenler toplumun ortalama \%13-15'ini oluşturur. Eregenlik çağı Dünya Sağlık Örgütünün önerisi ile 10-19 yaşlar arası olarak kabul edilmektedir. Ergenler gelişimsel, psikolojik ve tıbbi açıdan hem çocuklardan hem de yetişkinlerden belirgin olarak farklıdır. Ergenlik döneminde görülen romatizmal hastalıkların özellikleri hem çocukluk hem de erişkin döneminde görülen bulgulardan farklılıklar içermektedir. Ergenlerdeki romatizmal hastalıklar ile ilgili bir diğer önemli sorun ise çocuk romatoloji uzmanlarınca izlenen çocukların erişkin romatoloji hekimlerine devredilmesidir (1-8). Bu derlemede ergenlik döneminde görülen romatizmal hastalıklar klinik özellikleri, tanı ve tedavi yaklaşımları gözden geçirilecektir.

\section{1- Enfeksiyon ilişkili artritler}

Ergenlik döneminde hematojen yayılımla oluşan septik artrit ve osteomiyelitin oluşma oranı çok düşüktür. Ama çocuklarda çeşitli viral ve bakteriyel artritler görülebilir. Bunların başında Neisseria Gonorrhoeae'nin yol açtığı gonokoksoksik artrit gelir. Gonokokosik artrit sıklıkla üretral akıntı ile birlikte olan diz artriti ile karakterizedir. Artrit akut özellikte gidiş gösterir. Non-gonokokaksal artritler daha çok stafilokok ve streptokok enfeksiyonlarından sonra ortaya çıkar. Ülkemizde özellikle akut kalça artritlerinde Bruselloz ayırıcı tanıda unutulmamalıdır. Süregenleşen kalça artriti ve bel şişlikleri ise ilk olasılık olarak akla Tüberküloz enfeksiyonunu getirmelidir.

Birçok viral enfeksiyonun özellikle kızamıkçık, kabakulak, parvovirüs B19, hepatit virüsleri, Epstein-Barr virüs, adenovirüs, ve koksakie B virüs enfeksiyonlarının gidişi sırasında ve sonrasında akut poliartritle uyumlu klinik tablo ortaya çıkabilir. Ortaya çıkan poliartrit oldukça iyi gidişlidir ve sekel bırakmadan kendiliğinden iyileşir (1-11).

Yazışma Adresi/Address for Correspondence: Dr. Özgür Kasapçopur,

İstanbul Üniversitesi Cerrahpaşa Tıp Fakültesi, Çocuk Sağlığı ve Hastalıkları Anabilim Dalı, İstanbul, Türkiye E-posta: ozgurkc@istanbul.edu.tr 
Reaktif artritler: Özellikle gastrointestinal ya da genitoüriner sistem enfeksiyonlarından sonra ortaya çıkan ve belirgin olarak alt ekstremiteye yerleşen oligoartritlerdir. HLA B27 doku grubu ile kanıtlanmış bir ilişkisi var ise tablo "Reiter sendromu" adını alır. Klinik tablonun en önemli özelliklerinden birisi de entesittir. Reaktif artritlerde etyolojik etkeni ortaya koyabilmek çok kolay değildir. Etyolojik etkenin belirlenemediği tablolar daha çok postenfeksiyöz artropati adı ile adlandırlır. Ama ülkemizde aksini kanıtlayana dek her akut, sekel bırakmayan, gezici poliartiti reaktif artritleri en özgün örneği olan akut romatizmal ateş olarak kabul etmekte yarar vardır. Bu yaklaşım oluşabilecek olan kalp etkilenmelerini önlemek açısından çok önemlidir (1-11).

Akut romatizmal Ateş: Akut romatizmal ateş (ARA), A grubu beta hemolitik streptokok enfeksiyonlarını izleyerek ortaya çıkan, birden çok sistemi tutabilen bir bağ dokusu hastalığıdır. Hastalık geçirilmiş streptokoksik üst solunum yolu enfeksiyonunu (ÜSYE) izleyen ilk 3 hafta içinde ortaya çıkar ve özellikle eklemleri, kalbi, beyni ve deriyi etkiler. Hastalığın en önemli ve süregen zararının kalp kapakları üzerine olmasından ötürü de ARA hala güncelliğini koruyan ve insan sağlı̆ı̆nı tehdit eden önemli sağlık sorunlarından birisidir (9-12).

\section{Epidemiyoloji}

Hastalık hemen hemen dünyanın her tarafında sık olarak görülmektedir. Fakat gelişmekte olan ülkelerde görülme sıklığı gelişmiş ülkelere göre daha yüksektir. Özellikle yaşam koşullarının kötü olduğu ve kalabalık yaşanılan bölgelerde ARA daha sık görülmektedir. ARA'nın görülme sıkığı, antibiyotiklerin yaygın olarak kullanılmasını izleyerek belirgin olarak azalmışıı. Yalnız hastalığın görülme sıklığının geçirilmiş streptokok enfeksiyonları ile doğrudan orantılı olduğu da unutulmamalıdır. Hastalık en sık 5-15 yaşları arasında ortaya çıkmaktadır (9-12).

\section{Etyoloji ve patogenez}

Akut romatizmal ateşin, A grubu beta hemolitik streptokokların neden olduğu ÜSYE’larını izleyerek ortaya çıktığı bilinmektedir (9-12).

\section{Klinik bulgular}

Hastalığın klinik bulguları oldukça değişken olmakla birlikte hastalık sıklıkla ateşli bir ÜSYE'yi izleyerek 2-3 hafta sonra başlar. Hastalar genelde üç farklı klinik tablo ile başvururlar. En sık görüleninde hasta akut olarak başlayan, büyük eklemleri tutan gezici poliartritle başvurur. İkinci tablo hastanın pankardit ya da kapak tutulumu ile başvurduğu durumdur. Üçüncü klinik tablo ise hastanın merkez sinir sistemi tutulumu sonucu gelişen Sydenham koresi ile karşımıza çıktığı durumdur (9-12).

Artrit: Akut romatizmal ateşte görülen artrit tipik olarak gezici, kısa süreli, sekel bırakmayan simetrik poliartrittir. Poliartrit özellikle büyük eklemleri ve alt ekstremiteyi tutar. En sık tutulan eklemler sırası ile dizler, ayak bilekleri, el bilekleri ve dirseklerdir. Artritin eklemleri tuttuğu süre 1-2 gün içinde değişir ve sürekli olarak farklı eklemler tutulabilmektedir. Tutulan eklemler oldukça ağrilıdır. Nadiren monoartrit şeklinde büyük eklem tutulumu da görülebilir. Özellikle genç erişkinlerde ve çocuklarda eklem tutulum oranı \%80'lere ulaşabilir. Eklem tutulumu bazen sessiz karditin habercisi olabilir. ARA'daki eklem tutulumu antienflamatuar tedaviye hızla yanıt verir ve sekel bırakmaksızın kaybolur. Ülkemizde aksi kanıtlanmadığı sürece her akut poliartrite mutlaka ARA düşünülmelidir (9-12).

Post-streptokoksik reaktif artrit: Son yıllarda yapılan birçok çalışmada kardit olmaksızın ortaya çıkan poststreptokoksik artritlerin ARA'dan farklı bir hastalık olduğu öne sürülmekte ve bu grupta yer alan hastalar "Post-streptokoksik reaktif artrit" (PSRA) başlığı altında incelenmektedir. Bu farklı tanımlamaya yol açan nedenler ise şunlardır: 1- PSRA'da streptokok enfeksiyonundan sonra geçen süre ortalama 1-2 hafta olmasına karşın, klasik ARA'da bu süre 3-4 haftadır. 2- Klasik ARA'da gözlenen artrit antienflamatuar tedaviye çok iyi yanıt vermesine karşın, benzer yanıt PSRA'da görülmemektedir. 3- Kardit olmadan ortaya çıkan bu tablo' da özellikle artritin ağırlı̆ı̆ı ve gidişi ana tablo' yu belirlemektedir. 4- PSRA'da tenosinovit ya da renal bulgular gibi eklem dışı tutulumlar da sıkça görülebilmektedir. Tüm bunlardan ötürü belki de ARA'nın inkomplet bir formu olan bu hastalık PSRA adı ile anılmaktadır. PSRA'da küçük eklem tutulumu görülebilir ve artrit süresi 6 haftaya kadar uzayabilir. PSRA'lı hastaların asetil salisilik asit tedavisine vermiş oldukları yanıt yeterli değildir. PSRA'daki önemli tartışma konularından birisi bu gruptaki hastalara uzun süreli penisilin profilaksisi uygulanıp uygulanmaması konusunda yapılmaktadır. Fakat son yillardaki genel inanış bu grupta yer alan hastalarda profilaksi uygulanmasının zorunluluğu konusundadır. Çünkü uzun süreli olarak izlenen PSRA'ı hastaların birçoğunda ileriki yıllarda kapak tutulumunun ortaya çıktı̆ı gösterilmiştir (9-12).

Kardit: ARA'da görülen kardit, pankardit şeklinde olup, kalbin 3 tabakasını birden tutar. Hastaların ortalama \%40'ında görülür. Kardit klinik değerlendirme de karşımıza organik üfürümler, kardiyomegali, konjestif kalp yetersizliği ya da perikardit şeklinde çıkabilir. En çok tutulan kapaklar sırası ile mitral ve aort kapaklarıdır. Ülkemizdeki genç nüfus açısından değerlendirildiğinde, edinsel kalp hastalıkları arasında birinci sırayı romatizmal kalp hastalıkları alır (9-12).

Kore: Hastalığın merkez sistemini özellikle de ekstrapiramidal sistemi tutmasının bir sonucu olarak ortaya çıkan tablo "Sydenham koresi"dir. Hastaların ortalama \%10'unda görülür (9-12).

Deri bulguları: Akut romatizmal ateşin gidişi sırasında nadiren görülen fakat hastalı̆ı tanılandıııı majör kriterlerden olan derialtı nodülleri ve eritema marginatum hastaların \%10'undan azında görülür. Derialtı nodülleri bir santimetreden küçük çaplı ve ağrısız nodüllerdir. Eritema marginatum ise sıklikla gövdeye yerleşen, kaşıntısız, merkeze doğru beyazlaşan, 1-3 cm çaplı eritematöz döküntülerdir (9-12). 
Laboratuvar bulgularl: Laboratuvar bulguları, ARA tanısında özgüllüğü olmayan, yalnızca tanıda yardımcı olabilen testlerdir. Laboratuvar testleri hem geçirilmiş streptokok enfeksiyonunun gösterilmesinde hem de enflamasyonun kanıtlanmasında ve izlenmesinde yararlıdır. Geçirilmiş streptokok enfeksiyonunu göstermede hastalardan alınacak olan boğaz kültürü oldukça yararılıır. Geçirilmiş streptokok enfeksiyonunu gösteren özgün antikor testleri olan anti-streptolizin-O (ASO), anti-DNAse B, anti-hyalüronidaz, anti-NADase ve antistreptokinaz da tanılandırmada kullanılmaktadır. Bu testlerden en çok kullanılanı ise ASO düzeyidir. Yalnız ülkemiz gibi streptokok enfeksiyonlarının yaygın olduğu ülkelerde sağlıklı toplumda da ASO düzeyi oldukça yüksek olduğu için ASO'nun ARA'daki tanı koyduruculuğu çok kısıtlıdır. Yüksek ASO değeri ancak şüpheli ya da belirgin ARA tablosunun olduğu durumda 3 haftalık ara ile yapılan ASO ölçümlerinde geometrik bir artış varsa anlamlıdır (9-12).

Tanı: Akut romatizmal ateşin tanısında 1992 yilında yeniden düzenlenmesi yapılan Jones ölçütleri kullanılmaktadır (Tablo 1). Tanı için 2 majör ya da 1 majör ve 2 minör bulgunun bulunması yeterlidir.

Tedavi: Akut romatizmal ateşin tedavisinde üç ana amaç vardır. Amaçlardan birincisi hastalığa yol açan streptokokların eradike edilmesi, ikincisi var olan enflamasyonun giderilmesi ve üçüncüsü ise yineleyen streptokok enfeksiyonlarından hastanın korunmasıdır. Streptokokların eradikasyonu amacı ile penisilinler kullanılmaktadır. Önerilen oral fenoksimetilbenzil penisilin $(50,000 \mathrm{IU} / \mathrm{kg}$ ya da $3 \times 1$ milyon $\mathrm{U})$ ya da prokain penisilin (800,000 U/gün) dir. Tek doz 1,2 milyon ünitelik benzatin penisilinin de eradikasyonu sağlayabileceği bildirilmektedir (9-12).

Enflamasyonu gidermek amacı ile yalnı artritin ya da hafif karditin bulunduğu durumlarda asetil salisilik asit (ASA) (80-100 mg/kg/gün, en yüksek doz 4 gr/gün) kullanımı

\begin{tabular}{|l|}
\hline $\begin{array}{l}\text { Tablo 1. Akut Romatizmal Ateş tanısında kullanılan } \\
\text { düzeltilmiş Jones ölçütleri }\end{array}$ \\
\hline Büyük ölçütler \\
\hline Kardit \\
Poliartrit \\
Korea \\
Eritema Marginatum \\
Derialtı nodülleri \\
\hline Küçük ölçütler \\
\hline Ateş \\
Artralji \\
Geçirilmiş romatizmal kardit \\
Uzamış PR aralı̆ı \\
Artmış eritrosit sedimantasyon hızı ya da C reaktif protein düzeyi \\
\hline Geçirilmiş streptokok enfeksiyonunu destekleyen bulgular \\
\hline Artmış ASO düzeyi ya da diğer streptokoksik antikorlar \\
Grup A hemolitik streptokokları gösteren pozitif boğaz kültürü \\
Geçirilmiş kızı öyküsü
\end{tabular}

önerilmektedir. Orta ya da ağır karditin bulunduğu durumlarda ise prednisolon (2 mg/kg/gün, en yüksek $60 \mathrm{mg} / \mathrm{gün}$ ) kullanımı önerilmektedir. Antienflamatuar tedavi 3 haftaya tamamlandıktan sonra doz azalıımı ile ilaçlar kesilebilir.

Streptokok enfeksiyonlarından korunma amacı ile hastaların tümünde başlangıç antibiyotik tedavisi 10 güne tamamlandıktan sonra üçer haftalık aralarla benzatin penisilin (1,2 milyon IU) enjeksiyonları önerilmektedir. Benzatin penisilin profilaksisinin karditsiz ARA geçiren hastalarda 20 yaşına kadar, karditle birlikte geçirenlerde ise ömür boyu sürdürülmesi önerilmektedir (9-12).

\section{2- Jüvenil idyopatik (Romatoid) artrit}

Jüvenil idyopatik artrit (JiA), ağılıklı olarak periferik artrit ile ortaya çıkan, endojen ya da eksojen antijenlerin patogenezinde rol aldığı bağışıklık siteminde artmış yangısal yanıtla belirginleşen süregen bir hastalıktır. Jüvenil idyopatik artrit, tekil bir hastalık olmaktan çok çeşitli klinik tabloların bir arada görülebileceği bir hastalıklar toplamıdır $(5,6,7,13)$.

\section{Jüvenil idyopatik artrit sınıflaması}

Hastalığın ana tanısal ölçütleri, 16 yaşından önce başlayan, 6 haftadan uzun süren, bir veya daha fazla eklemi tutan artritin varlı̆ıı ile eklem iltihabına neden olabilecek diğer nedenlerin dıșlanmasıdır. Her alt grup için bir bașlangıç, bir de gidiş (seyir) tipi değerlendirilmesi yapılmaktadır $(5,6,7,13)$.

\section{Klinik belirtiler}

Jüvenil idyopatik artrit başlığı altında incelenen alt grupların klinik gidişi ve özellikleri alt gruplara göre aşağıda anlatılacaktır. Ergenlik döneminde nadir görülenlerden bu derlemede söz edilmeyecektir.

Sistemik JiA: Gelişmiş ülkelerdeki JiA'lı hastaların yaklaşık \%10-20'sini sistemik JiA oluşturmasına karşın ülkemizdeki en büyük JiંA alt grubudur. Aralıklı farklı karakterli yüksek ateş ve diğer eklem dişı bulgularla karakterizedir. Etkilenen çocuklar genellikle 4 yaşından küçük olmakla birlikte herhangi bir yaşta da hastalık görülebilir. Ateş karakteristik olarak günde bir ya da iki kez 39,5 dereceye kadar yükselir. Daha sonra normale hatta normalin altına bile iner. Ateş gün içinde sabah ve akşam olmak üzere 2 kez pik yapar. Hastaların çoğunda ateşle beraber bedenin herhangi bir bölümünde çoğunlukla gövde ve proksimal ekstremitelerde pembe renkli, ateşin düşmesi ile beraber kendiliğinden sönen; bazen kașıntilı olabilen tipik olarak maküler, ortası soluk, bir santimetreden küçük döküntüler ortaya çıkar. Bazen hastalık sırasında, bir kısmında persistan artritin görüldüğü multipl eklem tutulumunun olduğu, hem küçük hem de büyük eklemlerin tutulduğu poliartiküler tip gelişebilir. Poliartrit geliştikten sonra tipik ateş ve döküntü atakları çoğunlukla kaybolur. Bu durumda hastalık poliartiküler tipten ayırt edilemez. Bazen hastalık sistemik belirtiler dışında herhangi bir klinik belirti göstermeden ataklar halinde yineleyebilir (ateş ve döküntü gibi). 
Plörezi ve özellikle de perikardit hastaların yaklaşık \%50' sinde görülür. Buna rağmen hastaların çoğu asemptomatiktir. Perikardit ve miyokardit steroid tedavisine çok hızı yanıt verir. Sistemik başlangıçlı Ji'A'lıarın hemen hemen tamamında ANA ve RF negatiftir. Eritrosit sedimantasyon hızı (ESH) belirgin olarak yükselmiştir ve çoğunlukla $100 \mathrm{~mm} / \mathrm{saatten}$ fazladır. Sistemik başlangıçlı JíA'ı hastalarda genellikle üveit görülmez. Ergenlik döneminde eklem tutulumu çok belirgin olmaksızın görülen monosiklik ya da polisiklik sistemik JiA oldukça selim gidişlidir ve antiromatizmal tedaviye çok iyi yanit verir $(5,6,7,13)$.

JIA'ya ikincil olarak gelişen AA tipi amiloidoz hastalığın önemli komplikasyonlarından birisidir. Ayrıca sistemik Ji'A'ı olguların gidişi sırasında bir ikincil hemofagositoz olan makrofaj aktivasyon sendromu görülebilir. Bu tablo yaşamı tehdit eden bir tablodur. Çocuklarda tüketim koagülopatisi ile ortaya çıkan tablo sıklıkla ölümcül olabilir. Hasatlığın ana bulgularına ek olarak akut faz göstergelerinde hızı bir düşme ve hipertrigliseritemi görülür. Tanı kemik iliğinde ikincil hemofagositozun gösterilmesi ile konulur $(5,6,7,13)$.

Oligoartiküler JiA: Gelişmiş ülkelerde en sık görülen JiA alt grubudur. Hastaların üçte ikisini kızlar oluşturur. Hastalık genellikle 1 ve 4 yaşları arasında başlar. Ergenlik döneminde çok nadir görüldüğü için bu derlemede bu at gruptan söz edilmeyecektir.

Poliartiküler JiA: Poliartrit Ji'A'ı hastaların yaklaşık \%30-40'ında görülür. Bu grupta 5 ve/ya da daha fazla eklem tutulumu vardır. Hastaların yaklaşık \%75'i kızdır. Hastalık 1-3 ve 8-10 yașlarında yoğun olarak görülür. Hastalık RF pozitif ya da negatif olmak üzere 2 alt gruba ayrlır. RF negatif hastalık tüm JiA'lıların \% 20-30'unu oluşturur. RF pozitif hastalık ise tüm JiA'lıların \% 5-10'nunu oluşturur. RF negatif poliartrit herhangi bir yaşta görülebilir. Ergenlik döneminde de sıkça görülebilir. Ancak RF pozitif hastalık 8 yaşından önce nadiren görülür. Her iki grupta da kızlar daha çok etkilenir. RF pozitif poliartiküler tip erişkin tip romatoid artritin çocuklardaki karşılığıdır. Başlangıçta artrit genellikle simetriktir. Elin küçük eklemlerinin tutulumu (özellikle proksimal küçük eklemler ve metakarpofalengeal eklemler) ve el bileği eklemlerinin simetrik olarak tutulumu tipiktir. Kalça, boyun, omuz, temporomandibuler eklem ve servikal vertebra tutulumu hastaların yaklaşık \%50'sinde görülebilir $(5,6,7,13)$.

Seropozitif poliartiküler Ji'A'lı hastalarda yakınmalar ani ya da sinsi başlangıçlı olabilir. Bu grup tüm Ji'A'ı hastaların \%5 'ini oluşturur. Bu grup hastalar çoğunlukla 8 yaşından büyük çoğunlukla da ergen çocuklardır. Eklemlerdeki yıkım ilerleyicidir ve çoğunlukla bir yıl içinde kalıcı deformite bırakır. Hastalığın aktivitesinin derecesine göre belirgin olarak büyüme ve gelişme geriliği görülebilir $(5,6,7,13)$.

Entezitle ilişskili Artrit (EIA): Bu grupta yer alan hastalar özellikle son 20 yıldan bu yana pediatrik romatolojinin önemli tartışma konularından birisini oluşturmaktadır. Çünkü bu çocuklar hem JiA özelliklerini hem de jüvenil spondiloartropati özelliklerini taşımaktadırlar. Bu çocuklar doğrudan ankilozan spondilit ya da iltihaplı barsak hastalığına bağlı spondilartrit tablosu ile başlamayan ancak zaman içinde spondilartritlerden birine dönüşme olasıllı̆ı taşıyan olgulardır. Batı serilerinde \%15-20, ancak ülkemizde ve bazı gelişmekte olan ülkelerde \%30-40'lara varan sıklıkta karşımıza çıkmaktadır $(5,6,7,13)$.

EIA çoğunlukla erkek çocuklarda görülür ve 10 yaşından sonra ortaya çıkar. Bu grupta yer alan çocukların en önemli özellikleri RF ve ANA'larının negatif olması, entesopatilerinin ve alt ekstremite artrit ya da artraljilerinin olmasıdır. Hastaların yaklaşık \%60'ında HLA B27 pozitif olarak saptanır $(5,6,7,13)$.

Entesopati, tendonların kemiğe yapışma bölgelerinin enflamasyonudur. En çok aşil tendonu etkilenir. Entesopati, yalnızca jüvenil spondiloartropatilere özgü bir bulgu değildir.

Bu grup hastalarda görülebilen eklem tutulumu çoğunlukla alt ekstremiteye yerleşen, asimetrik ve oligoartiküler tiptedir. Hastalarda artritin ortaya çı|ışını ateşli hastalıklar ya da travma provoke edebilir. Oligoartiküler JiA'dan en önemli farkı kalça ekleminin çok daha sık olarak etkilenebilmesidir. Ergenlik döneminde aksiyel iskelet sistemi tutulumu nadirdir. Eklem tutulumu steroid olmayan antienflamatuar ilaçlara hızla yanıt verir. Artropati yineler tarzda sürebilir ve bazen de uzun süren tam ya da parsiyel remisyonlar olabilir. Eklemlerde sekel oluşma oranı diğer gruplara göre daha azdır $(5,6,7,13)$.

Hastalığın gidişini etkileyen en önemli gösterge HLA B27 pozitifliğidir. HLA B27 pozitif olan olgularda ankilozan spondilite dönüşme oranı oldukça yüksektir ve hastalık sık sık yinelemeler ile sürer. Akut semptomatik üveit entezitle ilişkili artritli hastaların yaklaşık \%10-20' sinde görülür $(5,6,7,13)$.

Jüvenil psoriatik artrit (JPsA): Sedef artropatisi daha önce seronegatif spondilartritler grubunda ele alınmaktaydı. Genellikle 9-12 yaşları arasında başlar ve kız çocuklarında erkeklere oranla biraz daha sık görülür (3/2). Eklem tutulumu değişik klinik tablolar gösterir. Tipik olarak küçük eklemleri tutan asimetrik bir oligo ya da poliartrit olarak başlar. Distal interfalangeal (DiF) eklem tutulumu sedef artritini düşündürür. Genellikle bir ya da birkaç parmağın hem MCF, hem PiF hem de DiF eklemi birden tutulur ve daktilit tablosu ortaya çıkar. Etkilenen parmakta tırnaklarda çukurcuklar görülür (tırnak yenikleri-yüksük tırnak). Bazı hastalar ise sero-pozitif poliartiküler JíA'dakine benzer simetrik poliartrit ile karşımıza gelebilir $(5,6,7,13)$.

Sedefin deri bulguları bazen çok belirgin ve yaygın olabilir. Ancak bazı olgularda özellikle aramak gerekebilir. Tipik olarak sedef plakları eklemlerin ekstansör yüzlerine, saçlı deriye, umbilikal çukura ve perineye yerleşir. Tırnaklardaki sedef bulguları da oldukça tipiktir. Yüksük tırnak görünümü, subungal hiperkeratoz, onikoliz gibi değişiklikler artritle seyreden sedef olgularında \%60 oranında görülmesine karşılık, artrit olmayanlarda \%30-40 kadardır. 
Kronik ön üveit JPsA'da \%17 oranında görülmekte ve bunların \%60-70'inde ANA pozitif olarak bulunmaktadır.

\section{Tanı}

Jüvenil idyopatik artritin tanısı tamamı ile klinik ölçütlere dayanılarak yapılmaktadır. JíA tanısının konulabilmesi ve tam klinik tablonun oturması bazen uzun bir zaman dilimini alabilir. Hastalığın özgün bir laboratuvar verisi yoktur. Laboratuvar verileri yalnızca ayırıcı tanıda, alt gruplara ayırmada ve izlemde yardımcı olmaktadır. Tanıda mutlaka her hastaya göz ön kamara muayenesi yapılmalıdır $(5,6,7,13)$.

\section{Tedavi}

Tüm romatizmal hastalıklarda olduğu gibi JiA tedavisi de bir ekip işidir. Bu ekipte pediatrik romatolog, fizyoterapist, ortopedist, çocuk psikiyatristi ve hasta ailesi etkin olarak yer almalıdır. Tedavinin tıbbi boyutunda öncelikli amaç ağrının geriletilmesi, hastalık etkinliğinin baskılanması ve kısıtlanan hareket açıklığının geri kazanılmasıdır. Medikal tedavinin temelini oluşturan ilaçları yakından inceleyecek olursak çocuklarda en sık kullanılanlar non-steroidal anti enflamatuar ilaçlardır (NSAii). En yaygın kullanımı olan NSAil'lar ibuprofen, endometazin, tolmetin ve naproksen sodyumdur. Bu ilaçlar öncelikle 12 yaş altı çocuklarda kullanılmaktadır. Bu ilaçlar düşük dozlarda analjezik etki ile ağrıyı azaltırlar, ancak yüksek dozlarda antienflamatuar etki gösterirler $(5,6,7,13)$.

Tedavide çoğunlukla NSAil yalnız başına etkili olamadıkları için diğer uzun etkili ve daha güçlü antienflamatuar ilaçlara gereksinim duyulur. Özellikle oligoartrit ve entezitle ilişkili artritlerde Sulfasalazinin etkinliği yapılan çalışmalarda kanıtlanmıştır. Bu nedenle oligoartrit ve entezitle ilişkili artrit' li hastalarda sıklıkla kullanılmaktadır. Tedaviye yanıt 6-8 hafta sonunda alınır. İlacın kullanımdaki başlangıç dozu 10-20 $\mathrm{mg} / \mathrm{kg} / \mathrm{gün}$ olup, haftalar sonra doz $30-50 \mathrm{mg} / \mathrm{kg} / \mathrm{güne}$ çıkılır $(5,6,7,13)$.

Metotreksat erişkin romatoid artritinde (RA)'da olduğu gibi Ji'A'da da hastalığın prognozunu anlamlı olarak düzeltmiştir. JiA tedavisinde etkinliği kanıtlanmış ve yan etkileri oldukça az gözlenen uzun etkili bir ajandır. Tedavi dozu $0,5-1 \mathrm{mg} / \mathrm{kg} / \mathrm{hafta}$ ya da $10-20 \mathrm{mg} / \mathrm{m}^{2} /$ hafta'dir. Bu dozun üzerinde tedavi yanıtı değişmemektedir. Ağızdan, cilt altı ya da intramüsküler olarak verilebilir. Çoğu hasta tedaviye başlangıcın ilk 2-3 haftasında yanıt verir. Ancak tedaviye yanit bazen uzun sürebilir. Kemik iliği üzerindeki etkilerini azaltmak, bulantı, oral ülser, orta derecede saç dökülmesi gibi yan etkileri kontrol etmek için $1 \mathrm{mg} / \mathrm{kg} /$ gün folinik asit ya da folik asit eklenmesi önerilmektedir $(5,6,7,13)$.

Kortikosteroidler, antienflamatuar ilaçlar içinde en etkili olanıdır. Ancak yan etkilerinin fazla olması ve destrüktif eklem hasarını belirgin olarak önlememeleri nedeniyle kullanımı sınırıdır. Oligoartiküler tip hastalıkta özellikle monoartrit olarak kendisini gösteren büyük eklem tutulumunda intraartiküler steroid kullanımı oldukça yararlıdır. Bu amaçla metil prednizolon asetat ya da triamnisolon heksasetonid kullanılmaktadır. Bu yolla steroidlerin sistemik yan etkilerinden korunmuş olunur $(5,6,7,13)$.

Sistemik tip artrit grubunda steroidlerin oral ya da parenteral kullanımı sistemik bulguları belirgin olarak geriletir. Eklemdeki ağrı, şişlik, duyarlıık ya da hastalıkla ilişkili kardit, hepatit, pulmoner hastalığa ek olarak ateş, kaşeksi ve anemi gibi bulgular steroid tedavisine anlamlı yanıt verirken, eklemlerdeki destrüktif olaylar çoğunlukla devam eder. Hastanın yakınmalarının ve fizik bulgularının azalmasına bağlı olarak doz azalması yapılabilir. Nadir durumlarda $30 \mathrm{mg} / \mathrm{kg}$ gibi yüksek dozlarda pulse steroid kısa süreli şiddetli sistemik hastalı̆ı̆ baskılamak için parenteral yolla kullanılabilir $(5,6,7,13)$.

Biyolojik ajanlar: Metotreksata yanıt vermeyen özellikle erişkin RA'lı olgularda yeni tedavi seçenekleri ortaya konulmaktadır. Bu konuda en çok dile getirilenler anti TNF- $\alpha$ inhibitörü olan etanersept, infliksimab ve adalumimabtır. Bunların arasında JíA'lı çocuklarda kontrollü çalışmalar yapılmış ve dolayısı ile kullanım onayı olan sadece etanersepttir. Etanerseptin sistemik JIA'dan çok poliartiküler tipte etkili olduğu gösterilmiştir. Tedavi dozu 0,4 mg/kg/haftada $2 \mathrm{doz}$ olarak cilt altına uygulanır. Haftalık tek doz $0,8 \mathrm{mg} / \mathrm{kg} / \mathrm{doz}$ kullanımı da önerilmektedir. Anti IL-1 (anakinra, kanakunimab, rilonasept) ve anti IL-6 reseptör monoklonal antikorları (tokilizumab) da yeni önemli tedavi seçenekleri arasında sayılabilir $(5,6,7,13)$.

Jüvenil idyopatik artrit tedavisinde ilaç tedavisi tek başına yeterli olmamaktadır. Ilaç tedavisi ile eş zamanlı olarak mutlaka fizyoterapi de uygulanmalıdır. Hastanın etkilenen eklemlerine uygulanan aktif ve pasif egzersizler yanında deformitelerin oluşmasını engellemek ya da oluşanları düzeltmek amacı ile atelleme yapılır $(5,6,7,13)$.

\section{3- Sistemik lupus eritematozus}

Sistemik lupus eritematozus (SLE) etyolojisi tam olarak bilinmeyen, klinik ve laboratuvar bulguları çok çeşitli ve değişken olabilen, kronik, otoimmun ve multisistemik bir hastalıktır. Otoantikor üretiminin yanı sıra T ve B lenfositlerindeki bozukluklar, B hücre hiperreaktivitesi, hipergamaglobulinemi, anormal sitokin salııımı, dolaşımdaki otoantijenlerin ve immun kompleks bileşiklerinin yeterince temizlenememesi bu hastalarda görülen diğer immünolojik bozukluklardır. Hastaların \%98'inde ANA, \%50-80'sinde anti-çift sarmal DNA (anti-dsDNA) pozitif olarak saptanır. Jüvenil başlangıçlı SLE erişkin SLE ile karşılaşııııldığında daha ağır bir klinik gidiş gösterir. Hastanın başvuru bulguları halsizlik, ateş, kilo kaybı, miyalji gibi özgün olmayan belirtiler ile olabileceği gibi artrit, 
santral sinir sistemi tutulumu, serözit, nefrotik sendrom, deri bulguları gibi daha spesifik bulgular ile de olabilir. Multiorgan tutulumu olan, anormal kan sayımı ve idrar analizi saptanan hastalarda SLE ayıııcı tanıda mutlaka düşünülmelidir $(5,6,7)$.

Epidemiyoloji: SLE çoğunlukla doğurganlık çağındaki genç kadınlarda görülür ve sıklıkla tanı yaşı 15-35 yaşları arasıdır. Sekiz yaşından küçük çocuklarda SLE çok nadir olarak görülür. Erişkinlerde yıllık insidans 1,9-5,6/100,000 arasında iken, 15 yaş altı çocuklarda 0,5-0,6/100,000 olarak bildirilmiştir $(5,6,7)$.

Etyoloji: Sistemik lupus eritematozusa yol açan nedenler henüz tam olarak bilinmemektedir. Epidemiyolojik çalışmalar genetik, hormonal, çevresel etkenlerin immun bozukluğa ve otoimmünite gelişimine katkıda bulunduğunu göstermektedir $(5,6,7)$.

Klinik bulgular: Sistemik lupus eritematozus çocuk ve ergenlerde uzamış ateş, eklem ağrısı, saç dökülmesi, halsizlik, yorgunluk ve kilo kaybı gibi sistemik belirtilerle karakterizedir. Deri, iskelet ve kas sistemi ile böbrekler çocukluk çağı SLE hastalarında en sık tutulan organ sistemleridir. Pediatrik SLE hastalarına, Amerikan Romatoloji Derneği (ACR) tarafından 1997 yılında gözden geçirilerek yenilenen ölçütlere göre tanı konur. On bir tanısal ölçütten en az dört tanesinin varlığı SLE tanısı koymak için yeterlidir. Malar döküntü, plöretik göğüs ağrısı, nefrit ve ANA pozitifliği saptanan çocuklarda SLE tanısı kolaylıkla konulabilir (Resim 1). SLE'de görülen artrit akut başlangıçı sekel bırakmayan poliartrittir. Poliartrit tüm büyük ve küçük eklemleri tutabilir. SLE artriti sıklıkla ARA artriti ile karışabilir. Fakat bazı hastalarda tanı ölçütleri tam olarak oluşmadığı için kesin bir tanı koymak mümkün olmaz. Böyle hastalarda tedavi asla ertelenmemelidir $(5,6,7)$.

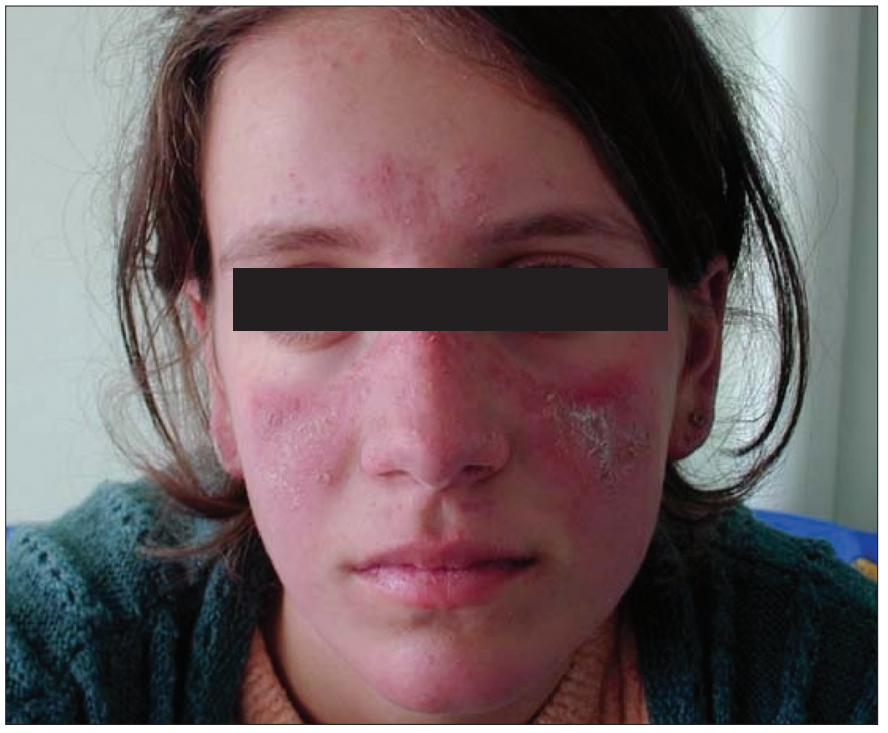

Resim 1. Sistemik lupus eritematosusta kelebek şeklinde döküntü
Laboratuvar bulguları: SLE tanıSı klinik ve laboratuvar bulgulara dayanılarak konur. Klinik olarak hastalıktan şüphe edildiğinde ya da ANA titresinde yükseklik saptandığında ek incelemeler gereklidir. Anti-dsDNA, anti-Sm, anti-SSA, antiSSB, anti-ribonükleoprotein antikorları, kompleman düzeyleri, tam kan sayımı, retikülosit sayısı, ESH, böbrek ve karaciğer fonksiyonları, idrar analizi ve mikroskobisi bu incelemelerden en önemlileridir $(5,6,7)$.

Tedavi: Sistemik lupus eritematozus tedavisinde, diğer romatolojik hastalıklarda olduğu gibi hastaların hayat kalitelerini arttırmak ve onları ilaçların istenmeyen yan etkilerinden korumak ana amaçtır. İzlenecek tedavi yöntemi, hastalığın etkinliğine ve organ tutulumuna göre farkllık gösterir. Genelde ateş, serözit, cilt ve lokomotor sistem belirtileri hafif hastalık tablosunu ifade eder. Bu belirtiler hidroksiklorokin ya da NSAil gibi düşük dozda ilaç tedavileri ya da kısa süreli steroid kullanımı ile kontrol altına alınabilir. Santral sinir sistemi tutulumu ve böbrek hastalığı ise ciddi, etkin hastalık belirtisi olarak kabul edilir ve daha agresif bir tedavi yaklaşımı gerektirir. Yüksek doz intravenöz steroid tedavisi, siklofosfamid ve azatiopurin gibi sitotoksik ilaçlar ve mikofenolat kullanılabilir. Hastalığın en sık görülen acil durumu ise belirgin pansitopeni ile ortaya çıkabilen lupus krizidir. Lupus krizi düşünülen hastalara yoğun yüksek doz steroid $(30 \mathrm{mg} / \mathrm{kg} / \mathrm{doz})$ tedavisi uygulanmalıdır $(5,6,7)$.

Ciddi nörolojik tutulum, sistemik vaskülit, ağır trombositopeni, hızlı ilerleyen glomerulonefrit ve diffüz alveolar kanama hastalarda acil müdahale edilmesi gereken durumlardır. Yüksek doz intravenöz steroid tedavisi ve siklofosfamid gibi sitotoksik ilaçlar kullanılmalıdır. Steroide dirençli ağır trombositopeni ya da yaygın alveolar kanama durumlarında intravenöz immunglobulin (IVIG) fayda sağlayabilir $(5,6,7)$.

\section{4- Jüvenil dermatomiyozit}

Jüvenil dermatomiyozit (JDM), çocukluk çağında nadiren görülen fakat aynı zamanda çocukluk ve ergenlik çağının en sık görülen idyopatik enflamatuvar miyozitidir. Özgün deri ve kas bulguları ile hastalık ortaya çıkar. JDM, sistemik bir vaskülit olması, ikincil maligniteler ile ilişkili olmaması, diğer çocukluk çağı enflamatuvar bağ dokusu hastalıklarılla örtüşebilmesi ve ylllar sonra yineleyebilmesi nedeni ile klinik olarak erişkin dermatomiyozitinden farklıdır. JDM deri ve kasların kronik bir vaskülopatisidir $(5,6,7)$.

Sıklık: Hastalık kız çocuklarında erkek çocuklara göre çok daha sık görülür. Hastalık çoğunlukla iki yaşından sonra tüm çocukluk çağında ortaya çıkabilir. Ortalama başlangıç yaşı 8-9 yaş arasındadır $(5,6,7)$.

Etiyopatogenez: Hastalığın nasıl oluştuğu ve hangi etkenlere bağlı olarak ortaya çıktığı net olarak ortaya konulamamıştır. Hastalık oluşumunda belirgin bir ailesel geçiş gösterilememiştir. Ama yapılan çalışmalarda hastalığın bazı doku grupları ile ilişkisi ortaya konulmuştur. Enfeksiyöz ve diğer çevresel etkenlerin hastalık oluşumundaki rolü çeşitli çalışmalar ile araştırımış ve net bir ilişki kanıtlanamamıştır $(5,6,7)$. 
Klinik bulgular: Klasik JDM'nin cilt döküntüleri sıklıkla ülseratif olabilen, malar bölgede bulunan karakteristik eritematöz döküntülerle birliktedir, fakat döküntü nazal labial kıvrımları ve burun köprüsünü geçip alına yayılır. Dudak birleşeklerinden aşağıya inmesi döküntüyü özellikle tipik sistemik lupus eritematosus döküntüsünden ayırır. Hastalı̆̆ın en özgün cilt bulgularından birisi olan heliotropik (ayçiçeğine benzer) döküntü özellikle göz kapağı çevresinde belirgindir. Döküntü özelikle üst kapakta belirgin olan bir morluk ile birliktedir (Resim 2). Hastalık boyunca klinik bulgular gerilese bile bu döküntü süregelir. Hastaların gövdelerinde yaygın bir eritematöz döküntü yer alır. Özellikle el ve ayak tabanlarında yaygın döküntü vardır. Eklemlerin ekstansör yüzlerinde belirgin papüler döküntüler yer alır. Hastalığın özgün cilt bulgularından birisi olan Gottron papülleri el parmak proksimal interfalengial eklemlerinin ekstansör yüzünde yer alır. Hastalı̆ın en önemli cilt bulgularından birisi de distrofik kalsinozistir. Kalsinozis bedendeki tüm yumuşak dokuların içinde yerleşebilir $(5,6,7)$.

Hastalı̆ın en önemli klinik bulgularından bir diğeri de kas bulgularıdır. Özelikle kalça ve omuz kavşak kaslarından kaynaklanan proksimal kas güçsüzlüğü en önemli klinik bulgudur. Çocuklar zorlukla hareket ederler ve sıklıkla Gower's belirtisi çocuklarda pozitiftir. Proksimal kasların yanı sıra solunum ve yutma kasları da etkilenebilir. Hastalarda artralji ve artritte görülebilir. Etkilenen eklemlerde fleksiyon kontraktürleri oluşabilir $(5,6,7)$.

Amiyopatik dermatomiyozit (JDM Sine Myositis): JDM yalnızca cilt bulguları ile ortaya çıkar. Hastalarda hiç kas tutulumu bulgusu yoktur. Fakat sıklıkla ayrıntılı kas gücü incelemeleri ve kas biyopsisi hafif kas tutulumunu ortaya koyar.

Vaskülopati ile Birlikte olan JDM: Vaskülopati ile birlikte olan JDM en ağır formdur. Hasarlanmış ve tıkanmış küçük arterler, venler ve kapillerleri gösteren klasik tırnak dibi kapiller değişiklikleri ile ortaya çıkar. Sıklıkla ülseratif deri lezyonları ve çoklu organ tutulumu vardır.

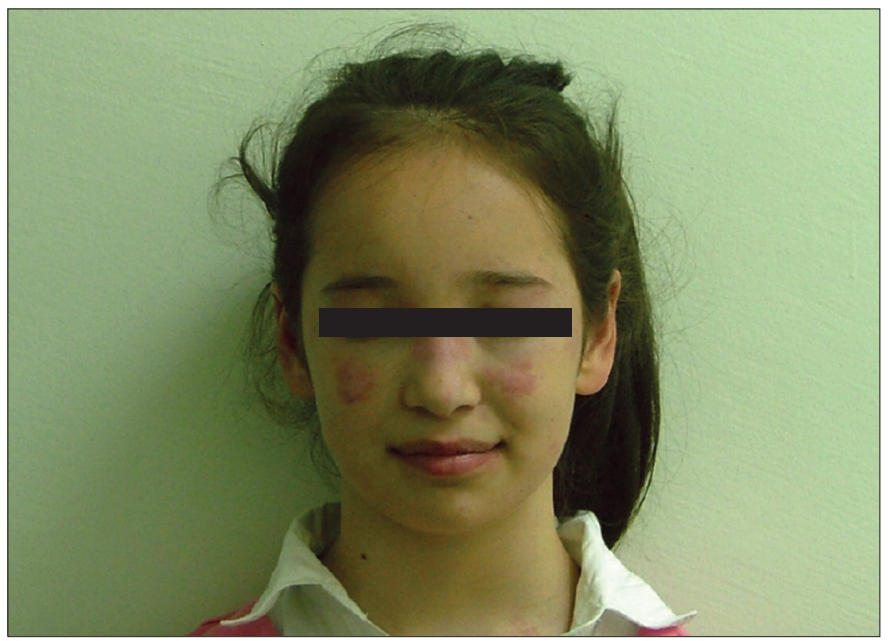

Resim 2. Jüvenil dermatomiyozitte heliyotropik döküntü ve yerel ödem
Diğer romatizmal hastalıklar ile birlikte olan JDM: Jüvenil dermatomiyozit sistemik lupus eritematosus ya da progresif sistemik skleroz ile birlikte görülebilir. Bu durumda eğer anti-RNP (ribonükleoprotein) pozitifliği var ise hasta karışık bağ dokusu hastalığı tanısı da alabilir.

Polimiyozit: Çocukluk çağında ortaya çıkan cilt bulguları olmaksızın yalnızca kas tutulumunun olduğu tablodur. Polimiyozit sıklıkla viral enfeksiyonları izler. Bu noktada hastaları mutlaka müsküler distrofilerden ayırt etmek gerekir. Müsküler distrofilerin en önemli bulgusu baldırda oluşan psödohipertrofidir. Bazı polimiyozitler sıklıkla süregen bir gidiş ortaya koyarlar $(5,6,7)$.

Laboratuvar Bulguları: Hastaların tümünde başlangıç döneminde kas enzim düzeyleri belirgin olarak yükselmiştir. Tedavi ile birlikte klinik düzelme var ise kas enzim düzeyleri hızla normale döner. Kas enzim düzeyleri aynı zamanda tedavi etkinliğini izlemede en önemli izlem ölçütlerinden birisidir. Kreatin fosfokinaz (CPK) genellikle normalin 5-20 katı yükselmiştir. Çok yüksek düzeyler rabdomiyoliz ya da muskuler distrofiyi düşündürür. Bazı hastalarda sadece bir ya da iki yükselmiş enzim olabileceğinden diğer enzimler (ALT, AST, LDH ve aldolaz) ölçülmelidir. Enzimler hastalığın erken evrelerinde tanıda yararlıdır fakat CPK kas kitlesi hasara ve atrofiye bağlı olarak küçüldüğü için sıklıkla normale döner. Bu nedenle enflamasyonun azalmasını gösterme açısından CPK'ya güvenilemez $(5,6,7)$.

Kas biyopsileri sadece tanıda şüphe varsa gereklidir, elektromiyografi çok nadir olarak gerekebilir tanıyı doğrulamada çok yardımcıdır.

Jüvenil dermatomiyozitte akut faz göstergeleri belirgin olarak yükselmiştir $(5,6,7)$.

Jüvenil dermatomiyozitli olguların hemen hemen yarısında ANA pozitiftir. Eğer başka antinükleer antikorlar varsa, özellikle Raynaud fenomeni ve sklerodaktili gibi diğer klinik özelliklerin varlığında, SLE ya da sklerodermayla örtüşme düşünülmelidir. Diğer miyozit spesifik antikorlar JDM'de çok nadiren görülür. Varlığı hastalık gidişini öngörmede işe yarayabilir $(5,6,7)$.

Radyolojik incelemeler özellikle kalsinozislerin gösterilmesinde işe yarar. Benzer şekilde MR inceleme çocuklardaki kas enflamasyonunu göstermede yararlı olacaktır.

Tanı: Hastalığın tanısı tamamı ile var olan klinik ölçütlere dayanılarak konulmaktadır:

- Karakteristik deri döküntüleri

- Simetrik proksimal kas güçsüzlüğü

- İskelet kası enzimlerinin yükselmesi

- Elektromiyografide kas tutulumunun gösterilmesi

- Tipik kas biyopsi bulguları

(Bohan ve Peter tanı ölçütleri, 1975)

Illk üç ölçütün varlığı tanı koymada yeterlidir. Hastalığı ayıııcı tanısında ise çocukluk çağında özellikle müsküler distrofiler unutulmamalıdır. Bundan ötürü miyopatili olgular mutlaka nöroloji ile ortak olarak değerlendirilmelidir $(5,6,7)$. 
Tedavi: Hastalık tedavisindeki ana yapı taşı kortikosteroidlerdir. Aktif hastalık döneminde başlangıçta yoğun yüksek doz steroid kullanımı önerilmektedir ( $30 \mathrm{mg} / \mathrm{kg} / \mathrm{doz}$ ). Hastalık bulguları baskılandıktan sonra kortikosteroid dozu olabildiğince en az doza indirilmelidir. Tedavi süresince steroid etkisini en az düzeye indirmek amacı ile tedaviye hemen metotreksat eklenmelidir. Metotreksatın kullanım dozu ise $15-20 \mathrm{mg} / \mathrm{m}^{2} /$ haftadır. Buna yanıtsızlık var ise tedaviye siklosporin A eklenebilir. Şiddetli deri hastalığı sistemik tedaviye karşın bir sorun olabilir. Hidroksiklorokin ya da kinakrin (meprakrin) tedaviye eklenebilir. İntravenöz immünglobülinler (IVIG) tedavide yardımcı olabilir. Şiddetli miyozit ya da Gi ya da pulmoner vaskülopati varlığında IV metilprednizolona ek olarak IV siklofosfamid tedaviye eklenebilir. Tedavinin en zor aşaması ise kalsinozisler ile başa çıkabilmektir. Bu durumda standart tedaviye eklenebilecek olan alendronatın etkin olabileceği yapılan çalışmalar ile gösterilmiştir $(5,6,7)$.

Fizyoterapi, enflamasyon kontrol altında olduğu sürece, hareket açıkığını korumak ve gücü yeniden kazanmak için

Tablo 2. Jüvenil sistemik skleroziste tanı ölçütleri

\begin{tabular}{|l}
\hline Büyük Ölçütler \\
\hline Sklerozis ve endürasyon \\
Sklerodaktili \\
Raynaud fenomeni
\end{tabular}

\section{Küçük Ölçütler}

Damarsal

Tırnak kapilloroskopi değişiklikleri

Parmak ucu ülserleri

Gastrointestinal

Disfaji

Gastroözofageal reflü

Renal

Renal kriz

Hipertansiyon

Kardiyak

Aritmiler

Kalp yetersizliği

Solunumsal

Akciğer fibrosisi

Pulmoner hipertansiyon

Kas iskelet sistemi

Artrit

Miyozit

Tendonlarda friksion kırıkları

Nörolojik

Nöropati

Karpal tünel sendromu

Serolojik

Antinükleeer antikor pozitifliği

Özgün antikor pozitifliği (anti-Scl-70, antisentromer)
JDM tedavisinde kullanılabilir. Fizyoterapist rehberliğinde kasları uzatma ve güçlendirme egzersizleri kas enflamasyonunu etkilemez. Bu nedenle hastalar, eğer uygun fizik tedavi başlatıırsa ve yatak istirahatına alınmazlarsa daha iyi fonksiyon elde etmeye eğilimli olurlar $(5,6,7)$.

\section{5- Jüvenil skleroderma}

Jüvenil skleroderma (JSkl), çocukluk çağında görülen ciltte sertleşme ile süregelen bir bağdokusu hastalıkları toplamıdır. Jüvenil sklerodermalı olgularda klinik bulgular ve gidiş çok çeşitlidir. Asıl sorun özellikle deride ve deri altı dokusundaki artmış kollajen depolanmasından ötürüdür. Bunun sonucunda ise fibrosis ve ciltte sertleşme ortaya çıkar. Skleroderması olan çocuklarda cilt değişik düzeylerde sert hissedilir. Jüvenil skleroderma birincil olarak deriyi tutarken değişik düzeylerde iç organ tutulumu da görülebilir. Ama iç organ tutulumu çocukluk çağında çok nadirdir. Hastalık organ tutulumuna göre sistemik ve yerel skleroderma olmak üzere iki ana başılı incelenmektedir $(5,6,7,14,15)$.

Jüvenil sistemik skleroz: Jüvenil sistemik skleroz (JSS), süregen, multisistemik bir bağ dokusu hastalığıdır. Çoğunlukla ergenlik döneminde ortaya çıkar. Hastalık sklerodermatöz deri değişiklikleri ve iç organ tutulumları ile birliktedir. Hastalığın gidişi sırasında özofagusta, akciğerlerde, mide-barsak kanalında ve kalpte fibrotik değişiklikler görülebilir. Hastalık tanısı geniş çaplı olgu serilerinin değerlendirilmesi ile oluşturulan tanı ölçütlerine göre konulmaktadır (Tablo 2). Hastalık çocukluk çağında çok nadirdir.

Hastalığın etyopatogenezi net olarak bilinmemektedir. Bilinmeyen bir uyarı ile aktive olan immünolojik olaylar silsilesi ciltte belirgin sertleşmeye yol açar $(5,6,7,14,15)$.

Klinik bulgular: Hastalığın klinik bulguları başlangıçta çok sinsidir. Tam olarak klinik tablonun oturması uzun yıllar alabilir. Cilt bulguları başlangıçta ödem ile birliktedir, daha sonra ödemin gerilemesi ile birlikte ciltte kalınlaşma ve fibrosis oluşur. Sklerotik değişiklikler bedenin her bölgesinde görülebilir. Özellikle yüzde dudak sulkuslarının silinmesi belirgin bulgulardan birisidir. Telenjiyektaziler ikinci sıklıkta görülebilen cilt bulgularıdır. Bu çocuklardaki vaskülite ikincil olarak ortaya çıkan bir bulgudur. Bu hastaların tırnak dibi kapillaroskopisinde de belirgin değişiklikler görülür. JSS'li çocukların çoğunda kalsinozis görülebilir. En sık görülen bir diğer klinik bulgu sklerodermatöz değişiklikler ile birlikte özellikle parmak uçlarında incelme ile oluşan sklerodaktilidir $(5,6,7,14,15)$.

Hastalığın büyük tanı ölçütlerinden olan Raynaud fenomeni hastaların yaklaşık \%70'inde görülür. Ergenlik döneminde görülebilen önemli sağlık sorunlarından birisidir. Özellikle soğukta belirgin olan uçlardaki morarma ile ortaya çıkan Raynaud fenomeni ısıtma ile birlikte geriler. Raynaud fenomeni 
önce beyazlaşma, ardından morarma ve kızarma üçlemesi ile birlikte ortaya çıkar. Morarma bazen çok ilerleyebilir. Buna bağı olarak özellikle parmak uçlarında belirgin doku ölümü görülür $(5,6,7,14,15)$.

Kas ve iskelet sistemine ait bulgular JSS'li olguların \%90'ında görülür. Bulgular artralji, artrit ve miyalji şeklinde görülebilir. Eklem tutulumu poliartiküler tiptedir.

Çocukluk çağı sklerodermasında iç organ tutulumu çok nadir olarak görülür. Gastrointestinal tutulum çocukluk çağında erişkin sklerodermasının aksine çok nadirdir. Disfaji olguların yaklaşık \%10'unda görülür. Hastaların çoğunluğunda gastroözofageal reflü görülür $(5,6,7,14,15)$.

Özellikle birden çok romatizmal hastalığın bir arada olduğu klinik tablolar çakışma (overlap) sendromları adı ile tanımlanmaktadır. Bu grup hastalıklara en çok eşlik eden hastalık ise sklerodermadır. Özellikle anti-ribonükleoprotein pozitifliği ile birlikte görülen hastalık grubu ise karışık (mikst) bağdokusu hastalığı adı ile anılmaktadır $(5,6,7,14,15)$.

Laboratuvar bulguları: Jüvenil sistemik sklerozlu olgularda kan sayımında süregen hastalık anemisi, hafif trombositoz görülebilir. Akut faz göstergeleri hafif yükselmiştir. Antinükleer antikor çoğunlukla benekli tipte pozitiftir. Fakat erişkin olguların aksine anti Scl-70 (anti-topoizomeraz I) sıklıkla pozitif değildir. Jüvenil sklerodermalı olgularda anti sentromer antikorları pozitif olarak bulunabilir. Anti fosfolipid antikorları pozitif bulunabilir $(5,6,7,14,15)$.

Jüvenil sistemik sklerozlu olgularda hastalık gidişi oldukça kötüdür. Fibrosis hızla ilerleyebilir. Erişkin döneme geçen çocuklarda iç organ tutulumlarına bağlı olarak ölümler görülebilir $(5,6,7,14,15)$.

Tedavi: Jüvenil sistemik sklerozun net bir tedavisi şimdiye dek bulunamamıştır. Başlangıç ve devam tedavisinde ilk seçilecek ilaç metotreksattır (10-20 mg/m²/hafta) . Metotreksat mutlaka kortikosteroidler ile birlikte kullanılmalıdır. Bu yolla anti fibrotik etki sağlanabilir. Eğer ekstremite uçlarında doku ölümü ya da iç organ fibrosisine ait bulgular oluşmuş ise tedaviye siklofosfamit yoğun yüksek doz ( $\left.1000 \mathrm{mg} / \mathrm{m}^{2} / a y\right)$ ile eklenmelidir. Raynaud fenomeninin ön planda olduğu olgularda tedaviye kalsiyum kanal blokerleri özellikle de nifedipin eklenmelidir $(5,6,7,14,15)$.

Yerel sklerodermalar: Çocukluk çağında en sık görülen skleroderma tipidir. Bu grup hastalıklar yalnızca deriye yerleşen sklerodermatöz değişiklikler ile birliktedir. Bu çocuklarda hiç iç organ tutulumu gözlenmez. Yerel skleroderma JSS'ye göre çocukluk çağında çok daha sık görülmektedir $(5,6,7,14,15)$.

Yerel sklerodermalarında oluşum mekanizmaları net olarak bilinmemektedir. Yalnız bu grup hastalığın oluşumunda kimyasal bulaşmayı, travmayı, bleomisin, bromokriptin, vitamin $\mathrm{K}$ gibi ilaçları suçlayan olgu bildirileri bulunmaktadır.
Ayrıca yerel skleroderma ile Borrelia Burgdorferi enfeksiyonu arasındaki ilişkiyi gösteren çalışmalar vardır $(5,6,7,14,15)$.

Klinik bulgular: Hastalardaki alt grup adlandırması lezyonun boyutlarına, yerleşimine ve tipine göre yapılmaktadır. Aşağıda sırası ile yerel sklerodermalar değerlendirilecektir:

Morfea: Cilt üzerinde yer alan sertliklere verilen isimdir. Özellikle belli bir bölgede yerleşenleri Morfea plağı adını alırlar. Ayrıca sıniflamalarda guttat morfea, keloid morfea, atrofik morfea ve büllöz morfea şekilleri de bulunmaktadır. Yaygın morfeada tüm bedende sertlikler vardır. Bu bölgeler dokunma ile belirgin olarak serttirler. Tutulan bölgenin rengi değişkendir, normal vücut renginden hiperpigmente lezyonlara kadar değişen görünümlerde olabilir $(5,6,7,14,15)$.

Lineer skleroderma: Çocukluk çağında en sık görülen yerel skleroderma tipidir. Özellikle tek bir ekstremitede ortaya çıkan belirgin sertlikler ile birliktedir. Lineer sklerodermanın bir alt grubu olan en coup de sabre (klıç yarası) de özellikle yüzün bir yarısında belirgin etkilenme vardır. Bu tabloya merkez sinir sistemi bozuklukları özellikle de intrakranyal kalsifikasyonlar eşlik edebilir. Bu durum edinsel ve enflamatuar kökenli iken, bir diğer benzer tablo olan ilerleyici hemifasyal atrofi (Parry-Romberg sendromu) genetik kökenli bir bozukluktur. İki hastalık arasında ayııı tanıyı yapmak çok zordur $(5,6,7,14,15)$.

Eozinofilik fasiit: Bu tablo özellikle kas fasyasını tutan yerel doku sertlikleri ile süregelen bir tablodur. Hastalarda hipereozinofili ve hipergamaglobülinemi görülebilir.

Yerel sklerodermalı olgularda iç organ tutulumu çok nadiren görülür. Ortaya çıkabilecek olan tutulumlar JSS'den farklı değildir $(5,6,7,14,15)$.

Laboratuvar bulguları: Yerel sklerodermalı olgularda özgün bir laboratuvar bulgusu bulunmamaktadır. Antinükleer antikor ve diğer otoantikorların pozitif bulunma oranı oldukça düşüktür. Bazı olgularda antikardiyolipin ve antihiston antikorları pozitif olarak bulunabilir. Tanılandırmada termografik incelemeler yardımcı olabilir $(5,6,7,14,15)$.

Tedavi: Yerel sklerodermaların tedavisinde kullanılan üzerinde uzlaşılmış bir tedavi seçeneği bulunmamaktadır. Ama grubumuzun da gösterdiği gibi bu grup hastalıklarda en etkin tedavi yöntemi metotreksat $\left(10-20 \mathrm{mg} / \mathrm{m}^{2} / \mathrm{hafta}\right)$ ve düşük doz steroid (10 mg/gün) seçeneğidir. Bu tedavi ile olgularında yaklaşık \%70'inde etkin bir tedavi sonucu elde edilmektedir $(5,6,7,14,15)$.

\section{Kaynaklar}

1. Davis K, Kopeman A. The spectrum of paediatric and adolescent rheumatology. Best Pract Res Clin Rheumatol 2006; 20: 179-200. (Abstract) / (Full Text) / (PDF)

2. Davis PJC, McDonath JE. Principles of management of musculuskeletal conditions in children and young people. Best Pract Res Clin Rheumatol 2006; 20: 263-78. (Abstract) / (Full Text) / (PDF) 
3. McDonagh, JE, Jordan A. Adolescent Rheumatology, In: Unsal E ed. Current Opinion in Pediatric Rheumatology, Nova Publisher: New York, 2007; 311-56.

4. Anthony KK, Schanberg LE. Assessment and management of pain syndromes and arthritis pain in children and adolescents. Rheum Dis Clin N Am 2007; 33: 625-60. (Abstract) / (Full Text) / (PDF)

5. Cassidy JT, Petty RE. Textbook of Pediatric Rheumatology. New York: Elsewier Saunders Company, 2005.

6. Maddison PJ, Isenberg DA, Woo P, Glass DN. Oxford Textbook of Rheumatology. London: Oxford University Pres, 2004.

7. Woo P, Laxer RM, Sherry DD. Klinik uygulamada pediatrik romatoloji. Kasapçopur Ö çev ed (s). İstanbul: Deomed yayıncilık, 2009.

8. McDonath JE, Kaufmann M. The challenging adolescent. Rheumatology 2009; 42: 872-5.
9. Kasapçopur Ö, Arısoy N. Çocukluk çağı romatizmal hastalıklarında ayırıcı tanı. Türkiye Klinikleri J Pediatr Sci 2008;4:7-11.

10. Kasapçopur Ö. Çocukluk çağı romatizmal hastalıklarına tanılandırıcı yaklaşım. İçinde: Yazıcı H, ed (s). Romatolojik Hastalıklar, Cerrahpaşa Tıp Fakültesi, Sürekli Tıp Eğitimi Etkinlikleri Dizisi No:34. İstanbul: Deomed yayıncılık, 2003; 43-50.

11. Kasapçopur Ö. Çocukluk çağı romatizmal hastalıkları. Sendrom 2008; 20: 65-76.

12. Kasapçopur Ö. Akut Romatizmal Ateş. İçinde: İliçin G ed (s). İç Hastalıkları. Ankara: Güneş Kitabevi, 2003; 2797-800.

13. Kasapçopur Ö, Özdoğan H. Jüvenil idyopatik artrit. Türkiye Klinikleri J Pediatr Sci 2008; 4: 31-42.

14. Kasapçopur Ö, Arısoy N. Jüvenil skleroderma. Türk Pediatri Arşivi 2006; 41: 60-4.

15. Zulian F. Systemic sclerosis and localized scleroderma in childhood. Rheum Dis Clin N Am 2008; 34: 239-55. 